\title{
Research \\ Weed species composition and growth in wheat field of mountain ecosystem Khokana, Lalitpur, Nepal
}

\author{
N. Sapkota ${ }^{1}$, B.R. Dongol ${ }^{2}$ and D.R. Bhuju ${ }^{1^{\star}}$ \\ ${ }^{1}$ Nepal Academy of Science and Technology, Khumaltar, Lalitpur, Nepal \\ ${ }^{2}$ Wildlife Conservation Nepal, Bafal, Kathmandu
}

\begin{abstract}
A study was carried out to determine the composition and predominance of weed species in wheat field in Khokana of Kathmandu valley as a representative sample of mountain ecosystem in Nepal. A total of 44 weed species representing 18 families were recorded. The most abundant species were Chenopodium album, Polygonum plebeium and Spergula arvensis. With the improved temperature after February, the weeds flourished in the late winter which had deterrent effect on the growth of wheat. Weeding practice was not much followed, while the fallowing gave more chances to weed species to germinate and grow. Periodic surveys on weeds help catalogue the existing weeds and extent of harm caused by them.
\end{abstract}

Key-words: Rice-wheat cropping practice, weed ecology, weed management.

\section{Introduction}

Wheat stands as the most important cereal crop after rice in Nepal, where rice-wheat cropping has been a popular farming practice. Of the total cultivated area in the country $(2,968,000$ ha), rice is cultivated in 1,544,990 ha and wheat in 669,014 ha. Eighty four per cent of the wheat cultivation area falls under rice-wheat rotational system (Singh and Paroda 1994). However, such type of rotational cropping has led to loss in yield of wheat (Joshi 1996). Nevertheless, the grassy weeds are also equally blamed for wheat yield (Aslam et al. 1989). An understanding of loss caused particularly by weeds, therefore, is important to explore successful approaches for preventing or minimizing such yield losses.

Those plants which usually grow where they are not wanted, and usually, interfere with the production of cultivated crops are considered to be weeds (Ranjit and Bhattarai 1988). Weeds are often defined as 'plants out of place', but this only considers the human view of a weed, not the fact that weeds

*Corresponding author, e-mail address: dineshbhuju@gmail.com are plants, which are ecologically in place, they are growing in an environment provided or managed by man which suits their needs. Weeds possess special plasticity in growth, which allows adaptation to varying conditions and very fast growth rates that give them advantages over crop (FAO 1987). Weeds reduce the crop yield either by reducing the amount of harvestable product (grain, stover, forage) or by reducing the amount of crop actually harvested (Aldrich 1984). The energy expended for the weeding of man's crops is sometimes more than for any other single human task (Holm 1971).

On account of the diverse climate, various intricate cropping systems are practiced in Nepal. Rice-based cropping systems are predominant in the lowland area of Nepal. As per the preliminary estimate of fiscal year 2005/2006, in lowlands of Nepal, under rice-wheat cropping system and out of total land under cultivation, wheat is cultivated on 381,243 ha with annual yield of 481,790 tons and productivity of $1.26 \mathrm{t} / \mathrm{ha}$ (CBS 1995).

The variegated geo-physical conditions in Nepal have created a hospitable environment for diversely adapted weedflora. There is a chronic problem of loss in crop yield due to 
weeds in agricultural land. The long persisting menace of weeds has still remained in spite of several revolutionary breakthrough in modern weed-control science and technology. Under the existing farming and gardening system, which in most of the cases are tradition bound, the various factors that cause serious infestation of weeds are such as half-hearted or neglected approach towards weed control, prevalence of mono-culture system thus facilitating vigorous multiplication and perennation of weeds, lack of provision for scientific cropping pattern, fragmentation of holding, use of input materials unrestrictedly contained with weed seeds and so on (Regmi 1999).

The present study was conducted with an objective to determine the composition and predominance of weed species in wheat field in mountain ecosystem of Nepal.

\section{Materials and Methods}

\section{STUDY AREA}

The study was carried out in the wheat farm in Khokana village (location: $27^{\circ} 38^{\prime} \mathrm{N}$ latitude and $85^{\circ} 18^{\prime} \mathrm{E}$ longitude) in Kathmandu valley, Lalitpur, Nepal. The study site is at the altitude of about $1325 \mathrm{~m}$ asl and is mainly an agriculture dominated landscape. Study of weed flora was conducted during wheat cropping season, i.e. January to April 2006.

\section{SAMPLING AND DATA COLLECTION}

Three different plots were selected and named as Plot P, Plot $\mathrm{Q}$ and Plot R. For each plot, five permanent quadrats were laid down, four at corner and one at the center. Altogether 15 quadrats of $1 \mathrm{x} 1 \mathrm{~m}^{2}$ were laid down for study in three different plots of the field.

Data were collected once after every two weeks for first two months starting from January and then once a week for last two months ending April during wheat cropping period. During the field visit, percentage cover, tallest height of the species and state of the plant species was recorded. Frequency, relative frequency and frequency class of the species appearing at different plots was determined.

Weed samples were collected from different plots of the study area. Collected specimen was tagged; important characters of weed, date of collection, collection site and its local name (as far as possible) were noted. All specimens were preserved and later identified using standard literature.

\section{Results and Discussion}

\section{SPECIES RICHNESS}

A total of 44 weed species (incl. 4 unidentified) belonging to 18 families was recorded (Appendix 1). Among the three plots, the number did not vary much with 33 in plot $\mathrm{P}, 32$ in plot $\mathrm{Q}$ and 37 in plot R. Weed coverage was found maximum in plot Q. This could be due to the reason that the field had good irrigation, while weeding practice was very less frequent and partially decomposed cow-dung was also used as fertilizer which might contain viable weed seeds.

The most dominant species on the basis of abundance scale in the study site were Chenopodium album, Eclipta prostrata, Spergula arvensis and Polygonum plebeium. Altogether, 4 dominant species, 9 frequent species and 21 occasional species and 10 rare species were reported. Family Compositae presented highest number of species (10 species), followed by Graminae (5). Study had been carried out in different plots with different microclimate; some plots were in shade and some were under sun throughout the day; some plots were relatively dry and some were overwhelmed with irrigated water. This could be the reason that a dominant weed in one plot becomes co-dominant or frequent in other plots.

Rajbhandari and Joshi (1998) have reported 208 weed species found in wheat fields of various geographic regions of Nepal, which constituted $57.1 \%$ of the total in the list prepared. Chaudhary (1979) reported 108 angiospermic weeds (14 monocots and 94 dicots) belonging to 36 families from six different sites of Kathmandu valley, viz. Thankot, Khumaltar, Dharmasthali, Indrayani, Bhaktapur and Kirtipur. The largest number of weed species belonged to Compositae followed by Graminae. Among the species, Chenopodium album, Polygonum sp., Vicia sp., Cannabis sativa were reported to the most abundant, which were all but one (Vicia sp.) were also found in the present study. However, the dominantly occurring species in the present study, S. arvensis, has been reported by Rajbhandari and Joshi (1998) in rape fields.

\section{SPECIES EMERGENCE AND COVERAGE}

In the first week of observation, at least four weed species appeared which reached to the maximum of 12 in plots $\mathrm{P}$ and $\mathrm{Q}$ in the seventh and sixth week, respectively; while the number reached 14 in plot $\mathrm{R}$ in the fifth week (Fig. 1). The limitation of species number after some period can be attributed to the competition for resources and to the smaller size of the 
Table 1. Frequency, frequency class, relative frequency and cover-abundance scale of different species in Plot P.

\begin{tabular}{|c|c|c|c|c|}
\hline Species & Frequency $\%$ & Frequency class & Relative frequency $\%$ & Cover-abundance scale \\
\hline Spergula arvensis & 100 & $\mathrm{E}$ & 6.57 & 5 \\
\hline Stellaria media & 100 & E & 6.57 & 3 \\
\hline Lathyrus sativus & 60 & $\mathrm{C}$ & 3.94 & 2 \\
\hline Polygonum plebeium & 100 & E & 6.57 & 5 \\
\hline Persicaria sp. & 40 & B & 2.63 & + \\
\hline Chenopodium album & 100 & E & 6.57 & 1 \\
\hline Blumea lacera & 80 & $\mathrm{D}$ & 5.26 & 1 \\
\hline Eclipta prostrata & 100 & E & 6.57 & 2 \\
\hline Sida rhombifolia & 20 & A & 1.31 & 3 \\
\hline Vernonia cinera & 40 & B & 2.63 & 3 \\
\hline Kyllinga brevifolia & 20 & A & 1.31 & 2 \\
\hline Tridax procumbens & 40 & B & 2.63 & 2 \\
\hline Bidens sp. & 40 & B & 2.63 & + \\
\hline Gnaphalium affine & 20 & A & 1.31 & 1 \\
\hline Unidentified & 20 & A & 1.31 & + \\
\hline Sporobolus indicus & 60 & $\mathrm{C}$ & 3.94 & 1 \\
\hline Conyza stricta & 20 & A & 1.31 & 2 \\
\hline Dichrocephala benthami & 40 & B & 2.63 & 2 \\
\hline Plantago erosa & 40 & B & 2.63 & 3 \\
\hline Unidentified & 20 & A & 1.31 & + \\
\hline Trifolium repens & 40 & B & 2.63 & 3 \\
\hline Cyperus difformis & 20 & A & 1.31 & 2 \\
\hline Polygonum hydropiper & 20 & A & 1.31 & 3 \\
\hline Unknown & 40 & B & 2.63 & $\mathrm{R}$ \\
\hline Emilia sonchifolia & 20 & A & 1.31 & 2 \\
\hline Unidentified & 20 & $\mathrm{~A}$ & 1.31 & + \\
\hline
\end{tabular}

Note: Cover-abundance scale: 5 - dominant, 4 - co-dominant, 3 - frequent, 2 - occasional, 1 - numerous up to $5 \%$ cover, + - few with small cover, R - solitary with small cover (Braun-Blanquet 1932).

Frequency class based on Raunkiaer (1934).

quadrat studied, though in totality the number of species reached 44 as mentioned above. In lowland wheat field of Birgunj, Dangol (1987) recorded a total of 35 species.

The coverage development corresponded with the species emergence as it reached maximum in the sixth week, except in the Plot $\mathrm{R}$ where the farmers had weeding removing almost all the weeds in the sixth week (Fig. 2). The development of weed coverage directly corresponded and/or influenced the wheat coverage, as when there was higher weed coverage the wheat coverage was lower (Fig. 3). For instance, in plot Q some $80 \%$ of weed coverage was recorded, which contained less than $10 \%$ of wheat seedlings during the early season. This indicated a deterrent effect of weed growth in wheat production as the weeds compete for nutrients, water, light and space. Generally an increase in one kilogram of weed growth corresponds to reduction in one kilogram of crop grown (Rajbhandari and Joshi 1998).
The maximum temperature in the month of January was below $25^{\circ} \mathrm{C}$ and minimum went below minus $3^{\circ} \mathrm{C}$ in the year of study. The temperature increased gradually in the following months; in April the maximum temperature crossed $30^{\circ} \mathrm{C}$ while the minimum did not go below $5^{\circ} \mathrm{C}$. The westerly also brought some rain in the late winter (March and April). Thus, the later part of the winter, that is, after February, was favorable for the vegetation to flourish.

Tables 1, 2 and 3 presents the frequency (\%), frequency class, relative frequency (\%) and cover abundance scale of each species in the three studied plots. Altogether 3 weed species, such as Chenopodium album, Polygonum plebeium, and Spergula arvensis qualified the frequency class $\mathrm{E}$ and cover-abundance scale 5 with frequency $100 \%$ in all three plots P, Q and R. Their relative frequency was above 5.0\%. Similarly, some 8 weeds such as Blumea lacera, Kyllinga brevifolia, Gnaphalium affine, Sida rhombifolia, Sporobolus 
Table 2. Frequency, frequency class, relative frequency and cover-abundance scale of different species in Plot Q.

\begin{tabular}{|c|c|c|c|c|}
\hline Species & Frequency \% & Frequency class & Relative frequency $\%$ & Cover-abundance scale \\
\hline Spergula arvensis & 100 & $\mathrm{E}$ & 5.95 & 5 \\
\hline Polygonum plebeium & 100 & $\mathrm{E}$ & 5.95 & 5 \\
\hline Cannabis sativa & 20 & A & 1.19 & 3 \\
\hline Plantago erosa & 40 & $\mathrm{~B}$ & 2.38 & 2 \\
\hline Chenopodium album & 100 & $\mathrm{E}$ & 5.95 & 2 \\
\hline Gnaphalium affine & 40 & $\mathrm{~B}$ & 2.38 & 1 \\
\hline Trifolium repens & 80 & $\mathrm{D}$ & 4.76 & 2 \\
\hline Bidens sp. & 40 & B & 2.38 & + \\
\hline Unidentified & 100 & $\mathrm{E}$ & 5.95 & + \\
\hline Juncus concinnus & 40 & B & 2.38 & + \\
\hline Kyllinga brevifolia & 80 & $\mathrm{D}$ & 4.76 & 1 \\
\hline Vernonia cinerea & 100 & $\mathrm{E}$ & 5.95 & 2 \\
\hline Dichrocephala benthami & 40 & $\mathrm{~B}$ & 2.38 & $\mathrm{R}$ \\
\hline Polygonum hydropiper & 20 & A & 1.19 & $\mathrm{R}$ \\
\hline Blumea lacera & 80 & $\mathrm{D}$ & 4.76 & 1 \\
\hline Centella asiatica & 20 & A & 1.19 & 1 \\
\hline Vernonica anagalis & 40 & $\mathrm{~B}$ & 2.38 & 2 \\
\hline Sida rhombifolia & 40 & $\mathrm{~B}$ & 2.38 & + \\
\hline Viola pilosa & 20 & A & 1.19 & + \\
\hline Ranunculus scleratus & 40 & $\mathrm{~B}$ & 2.38 & $\mathrm{R}$ \\
\hline Sporobolus indicus & 20 & A & 1.19 & + \\
\hline Emilia sonchifolia & 20 & A & 1.19 & 1 \\
\hline Convulvulus sp. & 20 & A & 1.19 & 1 \\
\hline Sacciolepis indica & 20 & $\mathrm{~A}$ & 1.19 & + \\
\hline
\end{tabular}

Table 3. Frequency, frequency class, relative frequency and cover-abundance scale of different species in Plot R.

\begin{tabular}{|c|c|c|c|c|}
\hline Species & Frequency \% & Frequency class & Relative frequency $\%$ & Cover-abundance scale \\
\hline Cannabis sativa & 100 & $\mathrm{E}$ & 4.54 & 3 \\
\hline Chenopodium album & 100 & $\mathrm{E}$ & 4.54 & 2 \\
\hline Polygonum plebeium & 100 & $\mathrm{E}$ & 4.54 & 4 \\
\hline Spergula arvensis & 100 & $\mathrm{E}$ & 4.54 & 2 \\
\hline Trifolium repens & 100 & $\mathrm{E}$ & 4.54 & 1 \\
\hline Plantago erosa & 80 & $\mathrm{D}$ & 3.63 & 1 \\
\hline Sacciolepis indica & 20 & A & 0.9 & + \\
\hline Stellaria media & 60 & $\mathrm{C}$ & 2.72 & 1 \\
\hline Blumea lacera & 100 & $\mathrm{E}$ & 4.54 & 2 \\
\hline Gnaphalium affine & 80 & $\mathrm{D}$ & 3.63 & + \\
\hline Sida rhombifolia & 80 & $\mathrm{D}$ & 3.63 & + \\
\hline Viola pilosa & 40 & B & 1.81 & 2 \\
\hline Dichrocephala benthami & 80 & $\mathrm{D}$ & 3.63 & 1 \\
\hline Cynodon dactylon & 100 & $\mathrm{E}$ & 4.54 & 1 \\
\hline Ranunculus scleratus & 20 & A & 0.9 & $\mathrm{R}$ \\
\hline Centella asiatica & 40 & $\mathrm{~B}$ & 1.81 & $\mathrm{R}$ \\
\hline Unidentified & 80 & $\mathrm{D}$ & 3.63 & + \\
\hline Unidentified & 20 & A & 0.9 & 1 \\
\hline Unidentified & 20 & A & 0.9 & + \\
\hline Sporobolus indicus & 80 & $\mathrm{D}$ & 3.63 & 1 \\
\hline Bidens sp. & 20 & A & 0.9 & 1 \\
\hline Convulvulussp. & 60 & $\mathrm{C}$ & 2.72 & 1 \\
\hline Unidentified & 40 & B & 1.81 & 2 \\
\hline
\end{tabular}

(C) 2010 Central Department of Botany, Tribhuvan University, Botanica Orientalis (2010) 7: 85-91 
Plot P

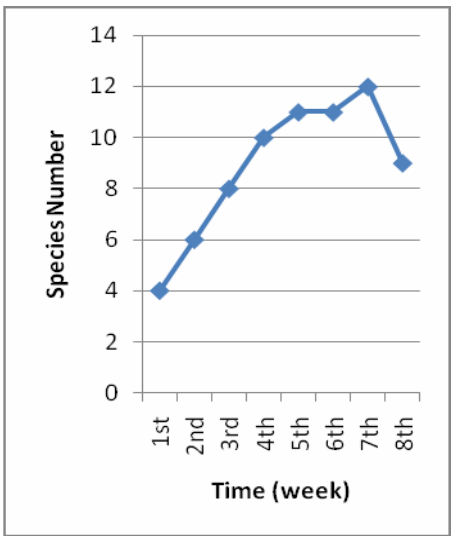

Plot Q

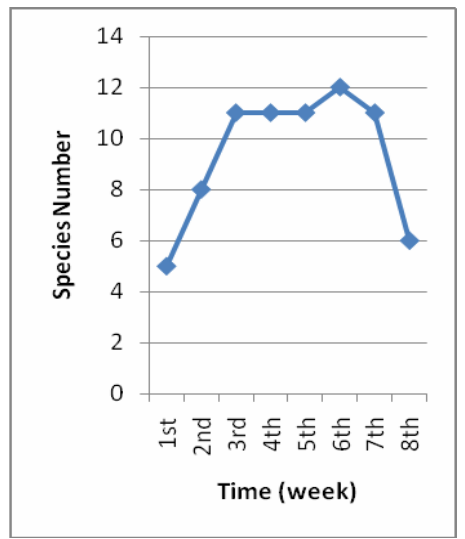

Plot R

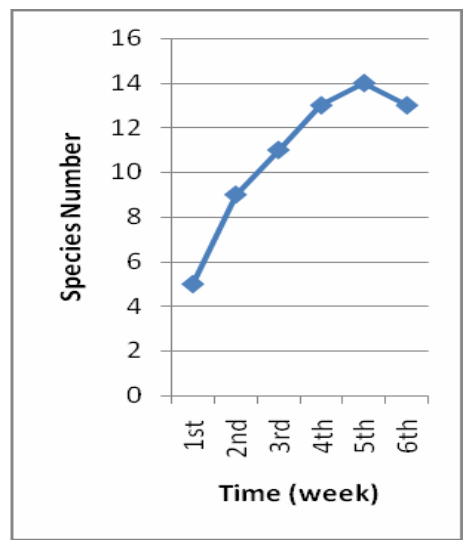

Figure 1. Species emergence in three study plots: P, Q and R.
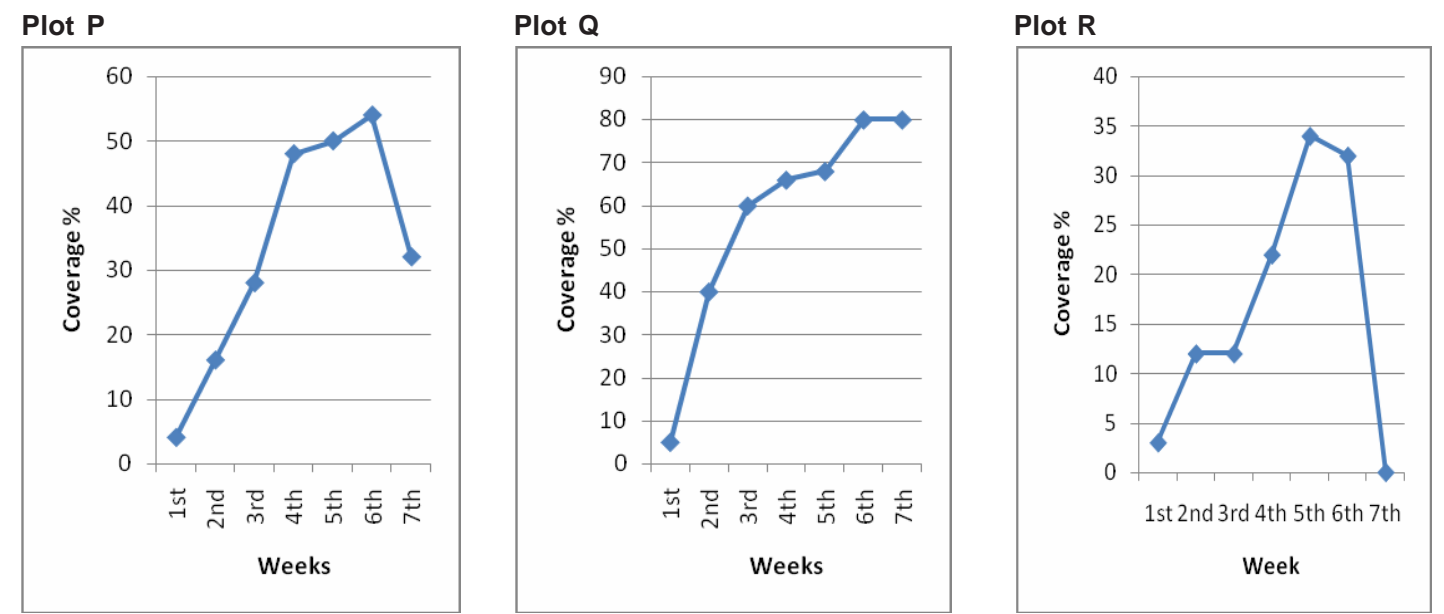

Figure 2. Coverage of weed in three study plots: P, Q and R.

indicus qualified for frequency class $\mathrm{D}$ with frequency of $80 \%$, though some of them varied in one plot or other.

In a study carried out in the wheat fields of mid-hill district Kabhre in central Nepal, Joshi and Gretzmacher (1999) recorded a maximum of 64 weeds, out of which 10 species were dominant and 20 were co-dominant. The authors also recorded higher number of weed species in wheat fields compared to that of rice fields in the same area. In the present study, two species out of 26 species (7.7\%) were dominant in Plot P, and two species out of 24 (8.3\%) in Plot Q were dominant with cover-abundance scale of 5 , while no such dominant species was recorded in the Plot R. Most of the species in the plots were occasional or less so with coverabundance scale of 2 or 1 (Tables 1, 2 and 3). Such occurrence scale varied with different species in different plots. Similarly, the relative frequency of the species varied from $6.57 \%$ (e.g.,
S. arvensis in Plot P) to $0.9 \%$ (e.g. Bidens sp. in Plot R). This requires further investigation to understand the resource partitioning and/or competitiveness among the species.

It was noted from the observation in the field study that the farming practice was most responsible for the emergence of a wide variety of weeds. Weeding practice was found low or irregular and the cattle were allowed to graze freely. In plot $\mathrm{Q}$, a massive weeding was observed in the seventh week, where the weed coverage abruptly decreased to almost zero (Fig. 2). However, such weeding is not regular. Nepali farmers usually do not weed out wheat fields and the degree of succession of weeds in their fields becomes invariably cumulative year after year (Joshi and Gretzmacher 1999).

Also, crop-rotation practice was found disregarded by the farmers in the site. Fallowing is considered to be a useful practice for nutrient recycling but during fallowing, weeds 

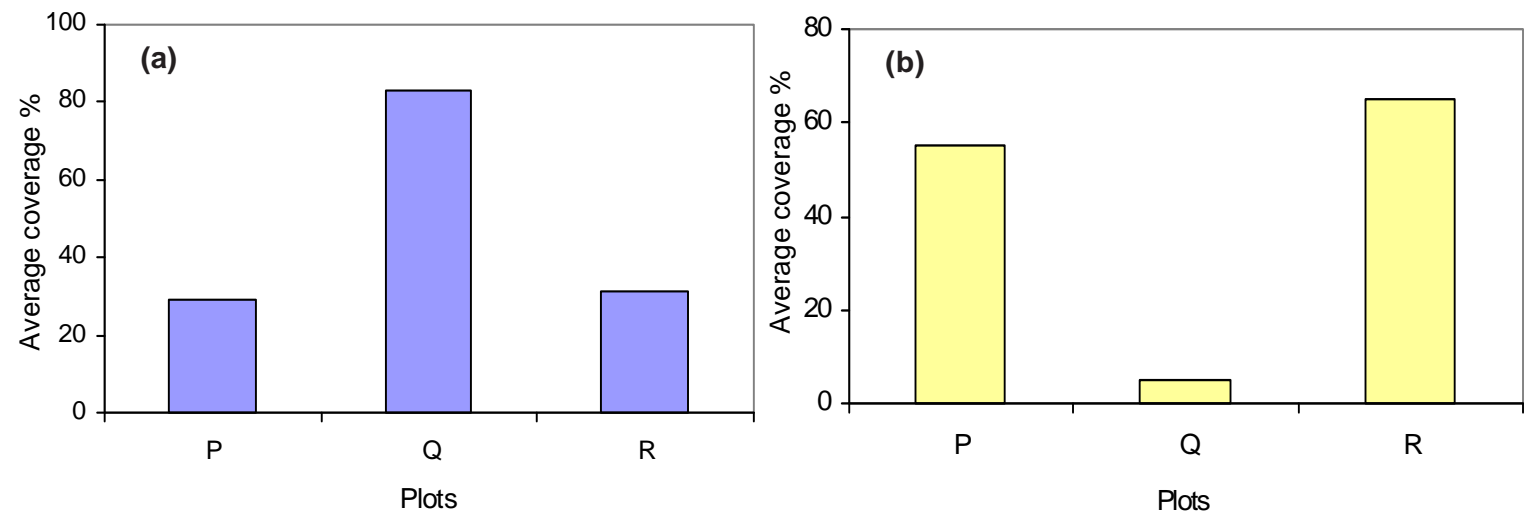

Figure 3. Coverage of weed (a), and wheat (b).

with their seeds having potent to germinate in next crop were allowed to grow as fodder of cattle. This practice is very helpful to enrich the seed bank in the soil, which paves way of vigorous weed emergence in the next batch of crop.

\section{Acknowledgements}

The first author was the recipient of NAST Research Assistantship. We express our thanks to the local farmers for allowing us to conduct our studies in their fields.

\section{References}

Aldrich R.J. 1984. Weed Crop Ecology: Principles in Weed Management. Breton Publishers, North Scituate, MA, USA.

Aslam M., Majid A., Hobbs P.R., Hashmi N.I. and Byerlee D. 1989. Wheat in the rice-wheat cropping system of the Punjab: a synthesis of on farm research results 1984-88. PARC/ CIMMYT, Islamabad, Pakistan Mimeograph 89-3 : 16-38.

Braun-Blanquet J. 1932. Plant Sociology: the Study of Plant Communities (Transl. by G.D. Fuller and H.S. Conard) Transl. of $1^{\text {st }}$ ed. of Pflanzensoziologie (1928). McGraw Hill, New York, USA.

CBS (Central Bureau of Statistics). 1995. Statistical Pocket Book Nepal. His Majesty's Government of Nepal, National Planning Commission, Kathmandu, Nepal.

Chaudhary R.P. 1979. Report on the weeds of wheat fields of Kathmandu valley. Journal of Natural History Museum 3(3): 83-93
Dangol D.R. 1987. Survey of weeds in wheat field at Birgunj, Parsa, Nepal. Journal of Institute of Agriculture and Animal Science 8: 45-51

FAO (Food and Agriculture Organization) 1987. Weed Science and Weed Control in Southeast Asia. FAO Plant Production and Protection Paper 81, FAO, Rome, Italy.

Holm L.R. 1971. The role of weeds in human affairs. Weed Science 19: 485-90.

Joshi M. 1996. Optimal Tillage and Weed Control Methods in Wheat under the Rice-Wheat Cropping System in Nepal. Ph.D. Thesis, University of Agriculture, Forestry and Renewable Natural Resources, Vienna, Austria.

Joshi M. and Gretzmachen R. 1999. Species composition and dominance of weeds in the rice-wheat cropping system of Kabhre District, Nepal. Nepal Journal of Science and Technology 1: 19-26.

Rajbhandari K.R. and Joshi R. 1998. Crop Weeds of Nepal. Natural History Society of Nepal, Kathmandu, Nepal.

Ranjit J.D. and Bhattarai A.N. 1988. Crop Weeds and Their Control in Nepal. Agriculture Research and Production Project, Winrock International/USAID. Project No. 367-0149-350002, Agronomy Division, Khumaltar, Lalitpur, Nepal.

Raunkiaer C. 1934. The Life Forms of Plants and Statistical Plant Geography: being the Collected Papers of C. Raunkiaer (Transl. by H. Gilbert-Carter, A.G. Tansley and Miss A. Fausboll). The Clanendon Press, Oxford, UK.

Regmi P.P. 1999. Common weeds. In: Nepal - Nature's Paradise: Insight into Diverse Facets of Topography, Flora and Ecology (T.C. Majupurea and R.K. Majupurea, eds.), pp. 159-169. M. Devi, Gwalior, India.

Singh R.B. and Paroda R.S. 1994. Sustainability and productivity of rice-wheat system in the Asia Pacific region: research and technology need. In: Sustainability of Rice-Wheat Production System in Asia, pp. 1-35. RAPA Publication, FAO, Bangkok. 
Appendix 1. Species composition of wheat weeds.

\begin{tabular}{|c|c|c|c|}
\hline SN & Latin name & Family & Local name \\
\hline 1. & Arenaria sp. & Caryophyllaceae & - \\
\hline 2. & Avena fatua $\mathrm{L}$. & Graminae & Jangali Jau \\
\hline 3. & Bidens sp. & Compositae & Kuro \\
\hline 4. & Blumea lacera (Burm. f.) DC. & Compositae & - \\
\hline 5. & Cannabis sativa $\mathrm{L}$. & Cannabaceae & Bhang \\
\hline 6. & Centella asiatica (L.) Urb. & Umbelliferae & Ghodtapre \\
\hline 7. & Chenopodium album $\mathrm{L}$. & Chenopodiaceae & Bethe \\
\hline 8. & Clerodendrum sp. & Verbenaceae & - \\
\hline 9. & Convolvulus sp. & Convolvulaceae & Halinkhur \\
\hline 10. & Conyza stricta Willd. & Compositae & Salahajhar \\
\hline 11. & Cynodon dactylon (L.) Pers. & Graminae & Dubo \\
\hline 12. & Cynoglossum sp. & Boraginaceae & - \\
\hline 13. & Cyperus difformis $\mathrm{L}$. & Cyperaceae & Mothe \\
\hline 14. & Dichrocephala benthami C.B. Clarke & Compositae & Chhuikejhar \\
\hline 15. & Eclipta prostrata L. & Compositae & - \\
\hline 16. & Emilia sonchifolia (L.) DC. & Compositae & mulapate \\
\hline 17. & Gnaphalium affine D.Don. & Compositae & Bokejhar \\
\hline 18. & Indigofera linifolia (L. f.) Retz. & Leguminosae & Kanikeghans \\
\hline 19. & Ipomoea purpurea (L.) Roth & Convolvulaceae & - \\
\hline 20. & Juncus concinnus D. Don. & Juncaceae & - \\
\hline 21. & Kyllinga brevifolia Rottb. & Cyperaceae & Mothe \\
\hline 22. & Lathyrus sativus $\mathrm{L}$. & Leguminosae & - \\
\hline 23. & Mazus surculosus D. Don & Scrophulariaceae & Ramnejhar \\
\hline 24. & Persicariasp. & Polygonaceae & Pirre \\
\hline 25. & Plantago erosa Wall. & Plantaginaceae & Isapgol \\
\hline 26. & Poa annua L. & Graminae & Antali \\
\hline 27. & Polygonum hydropiper $\mathrm{L}$. & Polygonaceae & - \\
\hline 28. & Polygonum plebeium R. Br. & Polygonaceae & Pirejhar \\
\hline 29. & Ranunculus sceleratus $\mathrm{L}$. & Ranunculaceae & Nakure \\
\hline 30. & Sacciolepis indica (L.) Chase & Graminae & Kaune banso \\
\hline 31. & Sida rhombifolia L. & Malvaceae & Barena \\
\hline 32. & Spergula arvensis $\mathrm{L}$. & Caryophyllaceae & - \\
\hline 33. & Sporobolus indicus (L.) R. Br. & Graminae & - \\
\hline 34. & Stellaria media (L) Vill. & Caryophyllaceae & Armalejhar \\
\hline 35. & Torenia sp. & Scrophulariaceae & Lehu \\
\hline 36. & Tridax procumbens $\mathrm{L}$. & Compositae & - \\
\hline 37. & Trifolium repens $\mathrm{L}$. & Leguminosae & - \\
\hline 38. & Unidentified & - & - \\
\hline 39. & Unidentified & - & - \\
\hline 40. & Unidentified & - & - \\
\hline 41. & Unidentified & Boraginaceae & Kanikekuro \\
\hline 42. & Vernonia cinerea (L.) Less. & Compositae & Shahadeva \\
\hline 43. & Vernonia sp. & Compositae & - \\
\hline 44. & Viola pilosa Blume. & Violaceae & Ghatteghans \\
\hline
\end{tabular}

